\title{
From Ambon to Poso: Comparative and Evolutionary Aspects of Local Jihad in Indonesia
}

\author{
KIRSTEN E. SCHULZE
}

KIRSTEN E. SCHULZE is an Associate Professor at the London School of Economics, the United Kingdom. Postal address: Department of International History, London School of Economics, Houghton Street, London WC2A 2AE, United Kingdom; e-mail: K.E.Schulze@1se.ac.uk.

This article looks at the first two local jihads in Indonesia after the fall of President Suharto: the 1999-2005 Ambon jihad and the 2000-07 Poso jihad. Both jihads were launched by Javanese mujahidin in response to the eruption of Christian-Muslim communal violence. The Ambon jihad was characterized by disagreement, infighting and lack of strategic direction, while the Poso jihad was comparatively better led and linked to the broader goals of establishing an Islamic state in Indonesia. This article explores the differences between the two jihads and asks to what extent the better organization of the Poso jihad was the result of lessons learnt from the "mistakes" of the Ambon jihad. The article advances two arguments. First, the Ambon jihad was undermined by the lengthy debate within Jemaah Islamiyah (JI) on how to respond to the Ambon conflict as well as by the shifting dynamics between JI, Mujahidin KOMPAK and Laskar Jihad. Second, that the Poso jihad was more organized than the Ambon one because JI's leadership had a more comprehensive approach to the Poso jihad; because JI and Mujahidin KOMPAK had learnt from the mistakes of the Ambon jihad in the areas of leadership, training, and using local jihads to achieve national aims; and because the intraand inter-mujahidin dynamics and with it the "state of jihad" had evolved between February 1999 and September 2000.

Key words: Ambon, Poso, Indonesia, jihad, Jemaah Islamiyah, Mujahidin KOMPAK

On 24 December 1998, an argument between a Muslim and a Christian youth over a screwdriver followed by the stabbing of a Muslim youth by a Christian later that evening triggered communal conflict in Poso, Central Sulawesi. ${ }^{1}$ Three weeks later, on 19 January 1999, a dispute between two Muslim youths and a Christian city transport driver over a bus fare ignited communal conflict in Ambon, Maluku. ${ }^{2}$ Both conflicts were rooted in socio- 
economic and political competition between Christians and Muslims. In both areas, local power-sharing arrangements had been undermined by three decades of President Suharto's centralization and migration policies. Both conflicts resulted in a lacklustre response from the Indonesian government as the communal violence on the periphery of the archipelago was deemed to be less urgent than the political struggles that were taking place in Jakarta following the fall of Suharto's New Order regime in May 1998. This provided an opening for jihadi volunteers from other parts of Indonesia, and gave rise to the Ambon and Poso jihads.

The Ambon and Poso jihads only partially overlapped with the Ambon and Poso conflicts. The Ambon jihad began after the first wave of violence in January 1999, during which Ambonese Christians had targeted Muslim migrants, destroying their market stalls, burning their houses and driving them out of Ambon. The Poso jihad started after the Walisongo massacre in May 2000 in which Muslim students and teachers from the Walisongo pesantren (Islamic boarding school), as well as Muslim migrants from the adjacent village, were hacked to death by Christians. Both jihads continued beyond the end of the communal conflicts in Poso in December 2001 and in Ambon in February 2002. The Ambon jihad waned after an attack on a police post in Loki on Seram island in 2005, while the Poso jihad temporarily ceased with a mujahidin-police shootout in Poso city's Tanah Runtuh neighbourhood in $2007 .{ }^{3}$ Both areas remain home to small extremist cells to this day.

This article examines the Ambon and Poso jihads from a comparative and evolutionary perspective. At the heart of this analysis are two interconnected questions: Why was the Ambon jihad so much more disorganized than the Poso jihad? And to what extent was the better organization of the Poso jihad the result of lessons learnt from the "mistakes" of the Ambon jihad? This article argues that the Ambon jihad was undermined by disagreements within one of the main jihadi organizations, Jemaah Islamiyah (JI), as well as by the shifting dynamics between JI and the other key jihadi groups, Mujahidin KOMPAK ${ }^{4}$ and Laskar Jihad. This article further posits that the Poso jihad was more organized than the Ambon jihad because JI's leadership had a different, more comprehensive, approach to the Poso jihad; because JI and Mujahidin KOMPAK had learnt from some of the mistakes of the Ambon jihad in the areas of leadership, training and using local jihads to achieve national aims; and because the intra- and inter-mujahidin dynamics, and with it the "state of jihad", had evolved between February 1999 and September 2000.

The Ambon and Poso jihads have not been examined in much detail in the academic literature on the violence during the post-Suharto democratic transition. This literature, as exemplified by writings of Jacques Bertrand, Gerry Van Klinken, Yukhi Tajima and Harold Crouch $^{5}$ has instead focused on the communal conflicts. It has examined the root causes of the 
violence, its links to the authoritarian policies of the New Order, the violence as an assertion of identity, and as an expression of the struggle over local resources as well as political power. Jihad in Ambon and Poso was only one element within the broader analysis of the conflicts, and more often than not, it was equated with Laskar Jihad as the most visible of the jihadi groups. The Ambon and Poso jihads have also been a side story in the literature on Islamist resurgence and jihad in Indonesia. John Sidel and Noorhaidi Hasan have referenced Ambon and Poso in their discussion of Laskar Jihad within the rise of militant Islamism in post-Suharto Indonesia. ${ }^{6}$ In their books on JI, Zachary Abuza, Greg Barton, Maria Ressa and Ken Conboy mention Ambon and Poso, but their overall focus is on JI's links with Al-Qaeda, JI's ideology and above all its violence and the threat it poses to Indonesia and Southeast Asia. ${ }^{7}$ The notable exceptions are Solahudin and Sidney Jones, who have examined the role of the Ambon and Poso jihads in the evolution of JI as well as mujahidin and jihadi activities in Ambon and Poso, and Greg Fealy and Chernov Hwang who have looked at local jihad in Indonesia and mujahidin disengagement. ${ }^{8}$ More coverage of these two jihads can be found in the small number of books and articles specifically on the Ambon and Poso conflicts. Writing on Ambon Bertrand, Dieter Bartels, Jeroen Adam, Badrus Sholeh and Sumanto Al-Qurtuby have examined the causes of conflict, the mobilization of society, the role of religion and efforts to resolve the conflict in Ambon. ${ }^{9}$ Loraine Aragon, Rinaldy Damanik and Dave McRae have done the same with respect to Poso. ${ }^{10}$ Aspects of jihadism in these conflicts have been explored by Kirsten E. Schulze and Birgit Bräuchler who examined Laskar Jihad in the Ambon conflict, ${ }^{11}$ and McRae and Tito Karnavian as well as Julie Chernov Hwang, Rizal Panggabean and Ihsan Fauzi who have looked at the role of the Javanese mujahidin in the Poso conflict, their affiliates Mujahidin Kayamanya and Mujahidin Tanah Runtuh, counter-terrorism efforts and jihadi disengagement. ${ }^{12}$ The Ambon and Poso jihads have also featured in the detailed reports published by the International Crisis Group and the Institute for Policy Analysis of Conflict. ${ }^{13}$ It is to this latter, more detailed, literature on the Ambon and Poso jihads that this article seeks to contribute.

Drawing upon a wide range of interviews conducted by the author between 1999 and 2018, this article starts by exploring the debate within JI after the Ambon conflict erupted in January 1999. It then proceeds to examine the role that the Muslim humanitarian aid organisation KOMPAK played during this early period in Ambon from January 1999 to mid2000, as a gateway to jihad. This is followed by an analysis of how and why the Poso jihad differed from the Ambon jihad, what lessons were learned from the "mistakes" of the Ambon jihad, and whether these lessons explain why the Poso jihad was so much better organized than the Ambon jihad. The article concludes with a discussion of the evolutionary aspects, looking 
at how intra- and inter-mujahidin dynamics evolved from the Ambon jihad to the Poso jihad.

\section{The Debate in JI on Ambon}

The eruption of conflict between Christians and Muslims in Ambon in January 1999 became the first big challenge for JI in Indonesia. JI was founded in 1993 by Indonesian clerics Abdullah Sungkar and Abu Bakar Ba'asyir while in exile in Malaysia. Headed by an amirSungkar until his death in November 1999 followed by Ba'asyir - and governed by a qiyadah markaziyah (Central Council), the organization was divided into four mantiqi (territorial divisions) across Southeast Asia: Mantiqi 1 covered Singapore and Malaysia; Mantiqi 2 encompassed Indonesia including Ambon but excluding Poso; Mantiqi 3 comprised the Southern Philippines, Sabah, Sarawak and Sulawesi including Poso; and Mantiqi 4, also referred to as Mantiqi Ukhro (the last mantiqi), covered Papua and Australia. ${ }^{14} \mathrm{JI}$ 's ultimate aim was to establish an Islamic state in Indonesia. At the time of the first wave of violence in Ambon, JI's leaders and many of its members had only just returned to Indonesia after the fall of Suharto in May 1998, and JI was still trying to find its feet on Indonesian soil.

The debate within JI on Ambon revolved around the nature of the conflict, whether JI should get involved and if so what JI's response should look like. Heated discussions were held both at the leadership level within JI's markaziyah and among its members for over a year. At different stages of this debate, the fault-line ran between Indonesians and Malaysians within JI, between Mantiqi 2 and the other mantiqis, and between JI's veterans of military training along the Pakistan-Afghanistan border in the period 1985-94 known as the "Afghan alumni" and the rest of JI.

Most Indonesian JI members regarded the Ambon conflict with considerable suspicion. Like other Indonesians at the time, many believed that the violence was a "dirty game" which had originated in Jakarta, in the circle of former President Suharto, and possibly engineered by the Indonesian military which had been pushed out of power. As Bali bomber Ali Imron recalled, there were two key questions that were being discussed: "What are they fighting about? And will this help or hinder us in our aim to establish an Islamic state?"15

In order to answer the first question, Sungkar asked JI's head of military operations, Zulkarnaen, to send an investigative team to Ambon. Zulkarnaen, an Afghan alumnus, had formed a special team known as Laskar Khos in 1998, mostly drawing upon other Afghan alumni. Ali Imron, who was part of Laskar Khos, became part of this initial JI investigative 
effort along with twin brothers Nurudin and Saifuddin, just after the first wave of violence had ended in February 1999:

We went there and talked to Muslim leaders, but not known ones and not politicians because we did not know who we could trust. They said they were attacked by the Christians and that they wanted to defend themselves. From what I saw, and the stories I heard, I got the impression that they needed lessons to prepare themselves - just some basic lessons on how to use a gun and how to make bombs, but the most important was fiqh jihad. ${ }^{16}$

Ali Imron only stayed in Ambon for three weeks. As he departed for the Philippines, Nurudin and Saifuddin stayed behind and started to teach fiqh jihad to some Ambonese Muslims. ${ }^{17}$ They also provided them with rudimentary training — such as handling firearms and bomb makingto prepare them for any further violence. ${ }^{18}$

At the same time, Sungkar also sought out Osama bin Laden's opinion on Ambon through Mukhlas, who led Mantiqi 1 together with Hambali and who was travelling to Afghanistan: "Bin Laden's reply was that to protect Islamic interests JI should take action."19 Together with the information gathered by JI's investigative team, this convinced the Afghan alumni that JI had to help the Muslims in Ambon defend themselves. In a subsequent JI markaziyah meeting in Malaysia, at which neither Mantiqi 2 nor Mantiqi 3 leaders were present, the decision was made to put Zulkarnaen in charge of JI's Ambon response and to send both Zulkarnaen and Mantiqi 1 leader Hambali to Maluku. ${ }^{20}$ This did not, however, end the debate within JI. In fact, it exacerbated it as Ambon was in the territory of Mantiqi 2. Indeed, according to Abu Rusydan, who was an influential leader in Mantiqi 2 and a JI markaziyah member, it was "after that [decision that] JI splintered". ${ }^{21}$

The fractures within JI came to the fore at a meeting Zulkarnaen organized in June 1999 in Solo attended by some 20 JI members "representing Solo, Lamongan, Central Java, East Java, Manado, and Jakarta", 22 including Laskar Khos members Zuhroni, Asep Darwin, Abdul Ghoni (alias Umaer), Sawad (alias Sarjiyo), Ali Imron and Mubarok. ${ }^{23}$ Heated debate took place at this meeting, with Mantiqi 1 members and Afghan alumni arguing that according to JI's General Guidelines for the Struggle of JI (known as PUPJI), “JI was obligated to struggle in Ambon as it was clearly a jihad difai (defensive jihad)." ${ }^{24}$ The head of Mantiqi 2, Abu Fatih, "was reportedly lambasted by several of those present... for being too slow and bureaucratic". ${ }^{25}$ On a different occasion, Sungkar, during a visit to Jakarta, "confronted senior Mantiqi 2 leader Achmad Roichan about why they were taking so long to act" and "Roichan responded that JI 
was not yet ready, that it needed to do more education and training to build up its social base before engaging in jihad." 26 Mantiqi 2 leaders had no intention of getting involved in the Ambon conflict despite the fact that Ambon was in their territory. ${ }^{27}$ They had sent their own investigative team which had concluded that this was not a religious conflict. ${ }^{28}$ Therefore they did not see this as a jihad sah (true jihad). ${ }^{29}$ They supported sending humanitarian aid but not fighters. Ultimately, they were unconvinced that the time was right for JI to embark on jihad in Indonesia as JI was clearly "still in the $i$ ' $d a d$ (preparation) phase". ${ }^{30}$

As a result, JI's Afghan alumni-a free-floating group outside the hierarchical structure - rather than Mantiqi 2 became the driving force and key players in the Ambon conflict. At that June meeting in Solo, Zulkarnaen assigned tasks to his subordinates, such as looking for weapons and explosives, recruiting people and preparing military training in Maluku. ${ }^{31}$ However, by this point some Afghan alumni, who were impatient with the debate in JI, such as Jibril, had already gone on their own initiative. ${ }^{32}$ As Jibril explained:

When we went to Ambon it was not an official JI decision. Zulkarnaen said that this was a jihad but others didn't agree. So it was a group of Afghan alumni who decided to go because our Muslim brothers were dying. Also as we had military experience from Afghanistan we had a responsibility to come to the defence of Muslims and to give guidance to the people. ${ }^{33}$

Similarly, fellow Afghan alumnus Farihin went to Ambon as what he termed "non-structural personnel" as he "could not wait for all the bureaucracy in JI" and "because they [Muslims in Ambon] were being slaughtered like goats". ${ }^{34}$ Farihin did not see "the need for agreement from Mantiqi 2". ${ }^{35}$ In fact, he "didn't need anyone's permission because Ambon was fardu ayn (an individual obligation)". ${ }^{36}$ Nevertheless, he also pointed out that "Abdullah Sungkar supported us going", and that Sungkar had always said that "the strong had an obligation to help the weak, and that if Muslim blood is being spilled "you have to go and help them". ${ }^{37}$

Even after the markaziyah decision had been made, JI members continued to go on their own initiative - a testament to the fracturing Abu Rusydan referred to. Some of these JI members were "frustrated with Zulkarnaen", 38 while others were frustrated with Mantiqi 2. Indeed, Mantiqi 2 continued to forbid its members to go to Ambon despite the markaziyah decision in what the head of JI Mantiqi 3 at that time, Abu Tholut, labelled as "the revolt of Mantiqi 2". ${ }^{39}$ The rift within JI deepened when Sungkar passed away in November 1999 and was succeeded by Abu Bakar Ba'syir who was a much more divisive figure and did not command the same respect as Sungkar. 
Eventually, in mid-2000, almost a year and half after the conflict had erupted, Mantiqi 2 permitted its members to depart for Ambon. This, according to Abu Tholut, was not because "they changed their mind about the nature of the jihad there, but because they were under a lot of pressure from their own members":

Everyone was sending volunteers to Ambon and people were asking questions why JI was not. The leadership of Mantiqi 2 had to answer a lot of questions. Mantiqi 2 was asked: you are jihadis, what is up with Ambon? Muslims from all parts of Indonesia and even foreign Muslims are going to Ambon, where are you? Muslims outside JI were sending people to Ambon - like Laskar Jihad. So JI members asked where are our leaders in this? Why are they silent? Mantiqi 2 members were confused. And in the end the Mantiqi 2 leaders agreed. ${ }^{40}$

The heated and at times acrimonious debate within JI during the first two years of the Ambon conflict undermined the Ambon jihad considerably. The divisions within the markaziyah, between the mantiqis, and between the Afghan alumni and the rest, damaged the credibility of the JI leadership at this crucial point of JI's first big challenge in Indonesia. It created uncertainties and a loss of confidence among JI members to the extent that hierarchies and command structures were by-passed as numerous JI members made their own way to Ambon. This individualistic and unstructured response of JI in turn made a well-organized jihad virtually impossible.

\section{KOMPAK: Gateway to Jihad in Ambon}

While the debate over Ambon paralysed and fractured JI, this was not the case for KOMPAK (Komite Aksi Penanggulangan Akibat Krisis, the Action Committee for Tackling the Consequences of the Crisis) which had a humanitarian brief. KOMPAK was established in 1997 by Dewan Dakwah Islam Indonesia (DDII) during the 1997-98 Asian Financial Crisis which had hit Indonesia hard. Its main aim at that point was to help ordinary Muslims by sending sembako (staple foods) to various areas that were suffering from the effects of the economic crisis. ${ }^{41}$ When the Ambon conflict erupted, KOMPAK's Solo branch, headed by Aris Munandar, was contacted by Ali Fawzi who was the head of DDII's Ambon branch. He asked KOMPAK to provide humanitarian aid — "sembako, clothes and tents for the displaced". ${ }^{42}$ KOMPAK responded quickly, becoming the first humanitarian organization to go to Ambon. Its volunteers brought the requested aid, documented the violence against Muslims and 
produced videos and video compact discs (VCDs) which helped raise awareness of the Muslim plight in Ambon and were instrumental in the recruitment of further volunteers. KOMPAK also sent doctors to Ambon's Al-Fatah hospital, including Aris Munandar's wife. ${ }^{43}$

In Ambon city, KOMPAK set up an office in Waihaong as well as a clinic, both in the same building. ${ }^{44}$ It was through this office that aid to Ambon's Muslims, and those on neighbouring islands, was channelled, including aid from Indonesian organizations such as the Medical Emergency Rescue Committee (Mer-C) and the Hidayatullah pesantren network. ${ }^{45}$ According to Abdullah Sunata, who headed the Waihaong office in 2000-01:

We were organizing the incoming humanitarian aid. It was very uncoordinated in the beginning. This was important especially for the smaller organizations. For instance, Hidayatullah sent aid from Balikpapan. They asked us for help. So we organized the shipping of the aid to Ambon and they took over from there. ${ }^{46}$

KOMPAK also assisted foreign Muslim charities such as the Saudi al-Haramain Islamic Foundation, which "came with their own people who distributed the aid and then returned". ${ }^{47}$ The distribution of all this aid, however, was often hindered by the violence on the ground. As Aris Munandar explained:

We distributed this aid across the islands and for that we had to bypass Christian areas. But the volunteers were not brave enough. Our primary mission became difficult to implement. We needed to defend our provision and distribution of aid. So KOMPAK decided to work together with the Javanese mujahidin to facilitate the passage of aid. This is how KOMPAK got involved in the conflict. ${ }^{48}$

The Javanese mujahidin in question were the Afghan alumni of JI, and the working relationship between them was an organic one as Aris Munandar himself was an Afghan alumnus and a member of JI. ${ }^{49}$ KOMPAK thus became the primary conduit for many JI members to go to Ambon not only "because JI did not have a framework for Ambon activities" 50 but also because it was safe as "KOMPAK was also JI." ${ }^{51}$ KOMPAK's cooperation with the mujahidin did not end there. According to Ali Imron, the Solo office "did the fundraising and sent it [the money] to Ambon to buy weapons and finance training". 52 He had met with Aris Munandar in Solo before heading to Ambon on his second visit: 
When I returned to Ambon the second time, I brought Aris Munandar's subordinates with me. I also went to find a place for a training camp that was near Ambon but not so close that the security forces would spot us. We found a place in Waimurat [Buru island]. The first people we trained were the KOMPAK members who had come with me. That's when Mujahidin KOMPAK started, but we did not use that name thenonly later when JI and KOMPAK separated. So I became the one who established Mujahidin KOMPAK. I was sent by JI but we could not use the JI name. ${ }^{53}$

The establishment of the Waimurat training camp was "the immediate result of the June 1999 decision" at Zulkarnaen's meeting in Solo. ${ }^{54}$ It was not only the first JI training camp on Indonesian soil, but it also became a key camp in facilitating the close social bonds of a new jihadi generation which outlasted the Ambon jihad and became the backbone of subsequent Indonesian involvement in other jihads such as Poso as well as Mindanao and Syria. ${ }^{55}$

The first batch of what later became Mujahidin KOMPAK was trained at Waimurat. And while Ali Imron had been instrumental in arranging this, it was Aris Munandar who became "the driving force" behind turning KOMPAK into "an organisation for 'freelance' mujahidin from all over Indonesia, although most recruits were from Java and Sulawesi". ${ }^{56}$ Indeed, KOMPAK's office in Waihaong became the contact and entry point for Javanese mujahidin from other organizations such as Darul Islam (DI), Negara Islam Indonesia (NII) and Laskar Jihad, as well as for mujahidin from Sulawesi "who were a mix of KOMPAK Selatan (KOMPAK South), Laskar Jundullah [the security wing of the Committee for the Preparation of Syariah in South Sulawesi] and Wahdah Islamiyah [a Makassar-based salafi organisation]". ${ }^{57}$ A small number of foreign mujahidin "mainly from Saudi Arabia but also Yemen, Syria, Jordan and Palestine", ${ }^{58}$ some of whom had links to Al-Qaeda, also entered Ambon through the Waihaong office. ${ }^{59}$ Thus, as JI volunteer Jibril put it, KOMPAK became "the centre of the jihadi forces with an office which was modelled on Osama Bin Laden's maktab al-khidmat [services office during the Soviet-Afghan mujahidin war], channelling both aid and mujahidin". ${ }^{60}$

The parallel with the maktab al-khidmat is instructive. It reveals the extent to which the Afghan jihad served as a blueprint in the minds of the Indonesian Afghan alumni. The establishment of a similar centralizing office in Ambon, moreover, demonstrates the ability to learn from previous jihadi experiences. The fact that it was KOMPAK rather than JI that established it shows how KOMPAK had some clear advantages as it was a legitimate, above ground humanitarian aid organization. But it also reflects the fact that KOMPAK was able to play this role as it was not hostage to the debate and divisions within JI. At the same time, it 
should be pointed out that KOMPAK's organizational role was limited to distributing aid, allocating bases to incoming jihadi groups and later providing military training. It did not, as will be seen in this article, extend to the battlefield.

During the first year of the Ambon conflict, only JI members and KOMPAK members went to Ambon through KOMPAK. KOMPAK volunteer Jek Harun, who was one of the first to arrive in Ambon, recalled that KOMPAK:

...immediately responded in Solo when the conflict erupted. We had a meeting, organized volunteers and gathered aid. The situation on the ground was bad. The houses were all burnt down in the attacks. So we decided to help with the rebuilding of the houses. ${ }^{61}$

Jek Harun became one of the coordinators who organized people going to Ambon:

The first group we sent had about ten persons. They were seniors [high-ranking jihadis] who went there to check out the situation. We videoed it to show it to the Muslims in Java to explain the situation. We explained that the victimhood was both physical and non-physical — and the non-physical was worse. They [Muslims in Ambon] lost the motivation to live. They asked us for help because we were their Muslim brothers. They were not brave enough so we needed to be brave for them. ${ }^{62}$

In December 1999, as another wave of violence swept through Ambon, KOMPAK opened its doors to volunteers from any background and "raised funds for them to go there" ${ }^{63}$ It also used humanitarian aid missions as a recruitment tool as the story of Aput, a student at Trisakti University in Jakarta, demonstrates. Aput was studying transport management at the time. His path to jihad in Ambon started at meetings of the Indonesian Committee for Solidarity with the Muslim World (KISDI). ${ }^{64}$ KISDI, which had raised awareness about the plight of Muslims in Palestine, Bosnia and Indian-occupied Kashmir during the Suharto era, now played a key role in raising awareness about the plight of Muslims in Ambon:

KISDI distributed the VCDs [made by KOMPAK] on the violence in Ambon. We had discussions about the situation and I felt called to go to Ambon to help. I became a volunteer for DDII to deliver humanitarian aid. I signed up with KOMPAK to go to Ambon. That was the end of 1999 or beginning of $2000 .^{65}$ 
Aput was tasked with delivering humanitarian aid:

I went to Waihaong bringing with me medicines and food for KOMPAK. Then I went to distribute the humanitarian aid. People were in dire need of medicine and in some areas the Muslims were starving. I was sent to deliver aid to Seram [a large island next to Ambon island] ... On the way we were shot at and I felt scared. When we arrived in Seram there was a five-year old child who had just been found killed. ${ }^{66}$

When Aput returned to the KOMPAK office in Waihaong after delivering the aid to Seram, Abdullah Sunata, who had become the head of the office in early 2000,67 "asked us whether we wanted to return to Java as our mission was completed or whether we would like to join the military training and help defend the Muslims". ${ }^{68}$ Aput decided to join the military training.

A similar experience also prompted a young Javanese KOMPAK volunteer calling himself "Abu Sayyaf" to join the military training. Abu Sayyaf had already joined KOMPAK during the financial crisis and had been a humanitarian aid volunteer ever since. After the Ambon conflict erupted, he decided to help his fellow Muslims there as well:

When I first came to Ambon, there was an incident where I was part of an aid convoy. We had a Brimob [mobile police] escort and then we were attacked by Christians and our Brimob escort just fled. That was when we took the decision to arm ourselves. During that attack two volunteers were killed and two were wounded, including one Brimob. ${ }^{69}$

KOMPAK also became the gateway for the last of the Javanese mujahidin organizations to enter Ambon - Laskar Jihad - a salafi organization which was established in January 2000, specifically in response to the government's inability to protect Ambon's Muslims as the conflict entered its second year. ${ }^{70}$ Laskar Jihad entered Ambon through KOMPAK in April 2000. As KOMPAK volunteer Ramly recalls:

The first Laskar Jihad delegation of seven was met by Abdullah Sunata. They came to the KOMPAK office in Waihaong. They wanted an area. As they had doctors, and Galunggung had a hospital, we gave them Galunggung. We also gave them a base in Kebun Cengkeh. ${ }^{71}$ 
Once Laskar Jihad had been allocated territory, its volunteers stopped going through KOMPAK, hinting at a rift that would open between Laskar Jihad and the rest of the Javanese mujahidin several months later and which would become yet another factor of anarchy in the Ambon jihad, as will be seen in the final section of this article.

\section{The Poso Jihad and "Correcting" the "Mistakes" made in Ambon}

In the second year of the Ambon jihad, another local Indonesian jihad front opened up in Poso. The Poso jihad came in response to the Walisongo massacre on 28 May 2000, when Christians attacked the Walisongo pesantren outside Poso city as well as the neighbouring village Sintuwulemba. Approximately 100 Muslims were killed, including 38 who had sought sanctuary in the pesantren's mosque. A six-man team of Mujahidin KOMPAK, led by Abdullah Sunata, arrived in early June 2000 directly from Ambon "carrying Rp 17 million [US\$1215] in cash and 14 guns". ${ }^{72}$ As in Ambon, KOMPAK's initial involvement came in the form of humanitarian aid, helping with the evacuation of bodies and providing community assistance, but also recording and documenting the violence that Christians had perpetrated against local Muslims. ${ }^{73}$ The Mujahidin KOMPAK team was followed by Ahmad Roichan, Muhammad Qital and Firmansyah from JI who established contact with Poso Muslim leader Haji Adnan Arsal, who had a pesantren in the Tanah Runtuh neighbourhood of Poso city. They offered him assistance and he accepted. ${ }^{74}$ Laskar Jihad did not arrive in Poso until after the Buyung Katedo massacre on 3 July 2001 in which 14 villagers were killed, 12 of whom were women and children who had been hacked to death with machetes while the imam was burnt alive in the village mosque. ${ }^{75}$

The Ambon and Poso jihads became "linked" as many of the mujahidin — belonging to all three organizations - came directly from Ambon, had previous Ambon experience or had formed clear opinions about the shortcomings of the jihadi response to the eruption of violence in Ambon. The Poso jihad thus presented an opportunity to "correct" past mistakes as well as an opportunity for JI's Mantiqi 3 to not only make its mark but to make it against Mantiqi 2. The Poso jihad benefitted from the more comprehensive approach adopted by Mantiqi 3 leaders Abu Tholut and Nasir Abas, who were intent on exercising better control over their own men as well as the locals. ${ }^{76}$ Due to the lessons JI and Mujahidin KOMPAK had learnt from the Ambon jihad, as well as the increased clarity in intra- and inter-mujahidin dynamics on the battlefield, the Poso jihad was more organized than the Ambon jihad. 
The mistakes of the Ambon jihad that were corrected in the Poso jihad broadly covered three areas: leadership, training and using local jihads to further the aim of establishing an Islamic state in Indonesia. The first and the third pertained particularly to JI and thus show Mantiqi 3's alternative approach, while the second, as will be seen, was a lesson learnt by both JI and Mujahidin KOMPAK.

\section{Leadership}

The first lesson learnt from the Ambon conflict was that a lack of clarity in leadership could seriously undermine jihadi efforts. JI's Ambon jihad, as discussed earlier, suffered from the divisions within the markaziyah and between the different mantiqis. As a result, the Ambon jihad was dominated by the Afghan alumni who operated outside the JI hierarchy and also saw a considerable degree of individual decision-making and action. By the time JI embarked upon the Poso jihad around September 2000, Mantiqi 2 had permitted its members to go to Ambon. This brought Mantiqi 2 in line with the rest of JI. Thus going to Poso was not the subject of great internal debate within JI as a consensus on local jihad had already been reached. Indeed, an agreed narrative was now being advanced as exemplified by Abu Rusydan's statement that "the main thing for JI with respect to the conflict in Ambon and Poso was the defence of the Muslims there. We were motivated to go there because we wanted to defend our brothers and defend our religion.",77

Leadership, however, was not just an issue at the central level but also in the field. Here JI Mantiqi 3 leader Nasir Abas pointed to the failures of Zulkarnaen in Ambon as something that should be avoided in Poso:

Zulkarnaen lost control over his men. That was a failure. Zulkarnaen was an instructor but not a leader. He was too strict. A leader needs to be a servant to his men. He needs to sit with them and laugh with them, just be together. But because of Zulkarnaen's leadership, his men became so frustrated that they joined KOMPAK. Others did their own activities. So JI failed to get their message to the local people. If you can't control your own men, how can you control the locals? ${ }^{78}$

The need to find a better link to the locals leads directly to the second lesson learnt from Ambon.

\section{Training}

The second lesson that JI and Mujahidin KOMPAK learnt from the Ambon conflict was that imbedding the training of local Muslims into a broader recruitment process produced better 
quality local mujahidin. Jihadi training in Ambon and Poso comprised two core elements: the training of Javanese volunteers and the training of local volunteers. In the Ambon jihad, Javanese mujahidin were trained in semi-permanent camps such as the Waimurat camp, while locals were trained in mobile camps which were set up in response to where the need was the greatest, in or near the villages of the local Muslims to be trained. The training of Javanese mujahidin lasted three months on average,${ }^{79}$ and included physical exercise, weapons training and religious instruction, particularly the teachings of Abdullah Azzam. ${ }^{80}$ The semi-permanent camps served a dual function. They prepared Javanese volunteers for fighting in Ambon and they provided "long term military training ... for carrying out the obligation of $i$ ' $d a d$ " ${ }^{81}$ The Ambon jihad was used both for recruitment as KOMPAK did and for "the caderization of the existing membership", ${ }^{82}$ as JI did. New recruits into JI could undergo training in Ambon rather than go to the JI camps in the Philippines. The training of Javanese volunteers was thus firmly embedded in broader organizational processes.

This was not the case for the training of local Muslims. The mobile training camps aimed at providing "short term military training ... to anticipate violence in and around Ambon". ${ }^{83}$ The standard training session in these mobile camps lasted two weeks on average, with a minimum of five days. While religious instruction was part of the training, "the focus of the training programme was on defence" 84 and on "survival skills". ${ }^{85}$ As in Ambon, mobile camps and semi-permanent camps were also established in Poso. However, unlike in Ambon, both JI and Mujahidin KOMPAK moved quickly from mobile training camps for training locals to setting up semi-permanent camps in their bases in the Kayamanya and Tanah Runtuh neighbourhoods of Poso city.

According to Nasir Abas, the training of local Muslims in Ambon was partially responsible for the disorganized nature of the Ambon jihad. Abas, who had been a trainer at JI's Camp Hudaibiyah in the Philippines for many years, believed that the key mistake was that the training in Ambon focused too much on military expertise and was not sufficiently grounded in Islamic teachings and JI's ideology. ${ }^{86}$ This resulted in Ambonese mujahidin trained by JI simply returning to their villages where they employed their new combat skills to defend their village but not necessarily to advance the Ambon jihad. While the content of the curriculum is significant, the fact that these Ambonese mujahidin were not recruited into an organization or included into a broader command structure led to JI's and Mujahidin KOMPAK's loss of control over the Ambonese they had trained almost as soon as they left the training camp.

Both the curriculum and the organizational disconnect were corrected in the Poso jihad by embedding the training of local Muslims into a broader recruitment process of local 
affiliates, Mujahidin Tanah Runtuh (JI) and Mujahidin Kayamanya (KOMPAK). This not only ensured that the military training was religiously and ideologically contextualized, but also that the newly trained had a place in a structured organization as well as a community to which they now belonged. Mujahidin Tanah Runtuh's recruitment process, as recounted by several of its members, exemplifies this. This process started with public pengajian (Islamic studies sessions) in local mosques from which regular attendees were selected for pengajian khusus (special Islamic studies sessions). This was followed by tadrib (military training) which included "the study of strategy, tactics, warfare and force formation. How to shoot, camouflage, making bombs, and protecting yourself from the enemy." ${ }^{87}$ It also included tafsir and fikh jihad. Tadrib was followed by more religious instruction through further pengajian khusus "going over the same religious material but more in-depth", and then "more weapons training, including handling weapons like M16s, SS1s, SKSs, M3s and M4s". ${ }^{88}$ After the second tadrib, the volunteers proceeded to the final stage of religious study - dauroh — where they focused on "jamaah (community), bai' at (loyalty oath) and khilafa (caliphate)", ${ }^{89}$ before proceeding to the bai' at and full induction..$^{90}$ This adapted version of the JI recruitment process enabled local mujahidin in Poso to defend their areas and to be better integrated into the Poso jihad, while ensuring that JI and Mujahidin KOMPAK, which had a similar but shorter recruitment process, had a greater degree of control over local mujahidin, and that Poso's Muslims were far more tied into the broader Indonesian jihadi project than Muslims in Ambon.

\section{Using Local Jihads for National Aims}

The third lesson learnt from the Ambon jihad was that local jihads in Indonesia could and should be exploited for the longer-term aims of establishing an Islamic state by focusing on the local population. Ambon never occupied a significant place in JI's Islamist imaginary, as JI saw Ambonese Muslims "as too heterodox and thus unlikely to be receptive to JI's message of shari'a-isation". 91 Thus no programme was devised for Ambon, despite discussions within JI that the organization would "conduct territorial instruction with the aim of forming a branch that would in the future become part of Mantiqi Ukhro, based in Australia", ${ }^{92}$ and despite individual JI members such as Ali Imron believing "that the Ambon conflict would be good place to recruit support for an Islamic state". ${ }^{93}$ The Ambon jihad never became part of JI's broader ideological plans. However, it did play a key role as the training ground for the next generation of Indonesian jihadis.

The Poso jihad stands in stark contrast to the Ambon jihad. Muslims in Poso were believed to be "far more serious in their Islamic observances" 94 and the area was seen as strategically important. Accordingly, JI devised a programme for Poso-known as Project 
Uhud - which the head of Mantiqi 3, Abu Tholut, was put in charge of. The initial aim of Uhud was to help Muslims in Poso defend themselves. However, after the Malino 1 Peace Agreement in December 2001, the aim changed to establishing secure base in Poso, "which would precede the establishment of an Islamic state" in Indonesia. ${ }^{95}$ Poso thus became JI's testing ground for the "much larger enterprise" of establishing an Islamic state in Indonesia, and the nucleus upon which the Islamic society necessary for this Islamic state would be built. ${ }^{96}$

According to Nasir Abas, the Uhud project was the direct result of the negative experience with Zulkarnaen in Ambon, who had failed to make an impact on Ambonese Muslim society. ${ }^{97}$ In order to reach out to the broader Muslim population in Poso and get their support, JI needed a programme and not just a military one:

In Poso it [this programme] was 80 per cent $d a^{\prime} i$ [preachers] and 20 per cent military guys - in Ambon it was all military. The da' $i$ 's function was dakwah [Islamic outreach] and tarbiyah [Islamic education]. The mosques in Poso were empty because of the conflict. So we filled the mosques with our ustadz. They recruited from the people and sent them to Tanah Runtuh. That is how you get the support of the locals. That's why we had influence in Poso but not in Ambon. And that is how we produced many radicals in Poso but not in Ambon. ${ }^{98}$

In April 2001, Nasir Abas succeeded Abu Tholut as head of Mantiqi 3 following a markaziyah meeting in Solo where JI's amir Abu Bakar Ba'asyir appointed him. This put Abas in a position where he could make plans for Poso, although as Abu Tholut emphasized, "there was no official decision to start using these areas to build a state. Those were private opinions-not from the markaziyah". ${ }^{99}$ Abas' vision was to turn Poso into JI's new economic area:

I wanted to turn Poso into our new economic area. Because of the conflict, the price of land was cheap. Farmers were scared to farm and were selling. I wanted to buy up this cheap land with coffee and cocoa trees. We had lost Mantiqi 1 Singapore and Malaysia which was our economic mantiqi. We could turn Poso into our new economic area and help Muslims there as well. I surveyed the territory around Poso. It was perfect for a qoidah aminah [secure base]. It would be similar to Basilan for Abu Sayyaf. We could bring in weapons and set up weapons factories and supply other areas in Indonesia. ${ }^{100}$

Abas believed that he would need approximately four years "to set this up and get our agrobusiness running” after which JI "could start establishing an Islamic state with Poso's Muslims 
at its core". ${ }^{101}$ Abas had already worked out his plans, but these were shelved when he was arrested in April 2003. Nevertheless, JI's closer relationship with Muslims in Poso outlasted the Poso jihad. At the same time, JI's ability to learn from its mistakes in the Ambon conflict regarding the use of local jihad for their broader aims as well as leadership, training and strategy ensured JI's resilience.

\section{Evolutionary Aspects from Ambon to Poso}

The Poso jihad also benefitted from the evolution of intra- and inter-mujahidin dynamics and the more general evolution of the "state of jihad" in Indonesia since the beginning of the Ambon jihad in February 1999. The Ambon jihad was characterized by competition within and between JI, Mujahidin KOMPAK and Laskar Jihad. This made devising an overall strategy difficult, and even resulted in armed clashes between jihadis. The tension among the mujahidin revolved around three issues. The first related to JI in Ambon whose members "were divided and made their own decisions". ${ }^{102}$ Zulkarnaen's inability to control his men resulted in JI members "joining other groups, especially KOMPAK as Aris Munandar paid them salaries". ${ }^{103}$ This was further exacerbated when Mantiqi 2 members were finally permitted to go to Ambon in mid-2000 as "they were subordinated to the Mantiqi 1 members already there and this caused command issues". 104

The second concerned relations between the various Javanese mujahidin and local Ambonese mujahidin. Laskar Jihad, in particular, was not well received by many in the population as they "forced themselves upon the locals". ${ }^{105}$ According to Ambonese Muslim leader Nasir Rahawarin, this was because "the Ambonese were shafi' $i$ while Laskar Jihad was salafi" and because Laskar Jihad not only applied shari' $a$ to its own but "wanted to apply it to everyone". ${ }^{106}$ When Laskar Jihad stoned to death one of its own members, Ambonese Muslims realized that "shafi' $i$ and salafi don't work together". ${ }^{107}$

The third related to the rift that opened between Laskar Jihad and the other Javanese mujahidin, who were now being collectively referred to as Laskar Mujahidin by the local population. ${ }^{108}$ Laskar Jihad differed from JI, DI, NII and Mujahidin KOMPAK in that it did not have its roots in the 1948-62 Darul Islam rebellions in which mujahidin had fought both the Dutch and Indonesian republican forces with the aim of establishing an Islamic state in Indonesia. ${ }^{109}$ Instead, Laskar jihad came out of the Indonesian salafi movement which had emerged in the 1980s. ${ }^{110}$ This impacted on how it viewed politics and jihad. As a salafi organization, Laskar Jihad was apolitical, disapproved of political parties as divisive and did not permit rebellion against a Muslim government. ${ }^{111}$ It also defined jihad in "broad terms as the taking of whatever actions are necessary to improve one's own faith" ${ }^{112}$ as opposed to the 
salafi-jihadis in JI who defined it in purely military terms as jihad-qital. All of these differences were clearly reflected in Laskar Jihad's Ambon mission, which not just aimed at defending Ambon's Muslims but also at fighting Christian separatism, spreading salafi Islam $^{113}$ and building schools and hospitals. ${ }^{114}$

After the brief period of cautious cooperation following Laskar Jihad's arrival in May 2000, Laskar Jihad started labelling JI, DI, NII and Mujahidin KOMPAK as khawarij (rebels). ${ }^{115}$ As Aput recalled:

They called us khawarij ${ }^{116}$ because we did not accept the state, political order and leadership. And they said that all those who did not side with them did not understand Islam. It was difficult with them. On the one hand, we were Muslim brothers, on the other, they did not treat us like that. ${ }^{117}$

Inter-mujahidin relations were not helped by Laskar Jihad's attitude and behaviour either. The other Javanese mujahidin were put off by Laskar Jihad's "military style hierarchy", 118 Laskar Jihad's insistence that "they were the elite", and the constant bragging "about their relations with the [Indonesian] military". ${ }^{119}$ This only confirmed suspicions among the mujahidin that Laskar Jihad was "working for [Indonesian] intelligence... to undermine us". ${ }^{120}$

In September 2001, after the more visible that Laskar Jihad had been repeatedly blamed for the attacks carried out by the others, ${ }^{121}$ Laskar Jihad and Mujahidin KOMPAK clashed openly in Kebon Cengkeh. ${ }^{122}$ Clashes also occurred in Ahuru. Indeed, antagonism had grown to such an extent that JI member Ali Fauzi, who was in Ambon during the Ahuru clash, "wanted to bomb the Laskar Jihad post in Kebun Cengkeh in response", ${ }^{123}$

As a result of these inter-mujahidin tensions, "there was no grand strategy in Ambon". ${ }^{124}$ Many attacks had very little planning and were driven by revenge. As Abdullah Sunata explained:

There were local triggers. For example, before we attacked Sirisori, Iha had been attacked by the Christians. .... Each case had a trigger. At Unpatti [University of Pattimura], there was a long history of discrimination against Muslim students and when the conflict erupted, Unpatti gave 100 per cent support to the Christians. The Muslim students were in an emergency campus near the hospital. That was the trigger. ${ }^{125}$ 
There was, however, a clear battle order. The average attack started with Muslim child fighters infiltrating the target area to set buildings on fire. ${ }^{126}$ The subsequent assault was led by those who had automatic firearms - Mujahidin KOMPAK, JI, DI or NII, sometimes supported by "pasukan siluman" (shadow forces) who were Muslim soldiers or police out of uniform. ${ }^{127}$ Then came the local mujahidin with an array of homemade as well as traditional weapons, including machetes, bows and arrows, spears and fishing bombs. ${ }^{128}$

The Poso jihad presented a much clearer strategic picture. By the time JI and Mujahidin KOMPAK went to Poso, the ambiguities in their relationship had been resolved. In 2000 they had started running separate training camps in Ambon after Mujahidin KOMPAK decided to open its doors to volunteers from all kinds of backgrounds earlier that year, although many of the trainers in the KOMPAK camps were still JI Afghan alumni. In Poso the separation was further underlined by the setting up of separate local affiliates. An equally clear, albeit hostile, boundary characterized the relationship between Laskar Jihad and the rest of the mujahidin. This ensured that unlike in Ambon, Laskar Jihad did not set up command posts in close proximity to the other mujahidin, thus reducing the possibility of clashes.

Laskar Jihad, which again came several months after JI and KOMPAK, set up a string of village defences as it had done in Ambon. It also perfected the catapult bomb, "a catapult mechanism" they had developed "to launch homemade bombs into Christian areas" and which had been "quite effective". ${ }^{129}$ As in Ambon, Laskar Jihad saw itself as protecting the unity and integrity of the Indonesian state, in this case convinced that Poso's Christians were intent on establishing a separate state of Toraja Raya. ${ }^{130}$ However, unlike in Ambon, it did not have a radio station, so its strategy lacked the psychological warfare element. In this sense, Laskar Jihad made less of an impact in Poso than it had in Ambon and was thus a far less relevant jihadi force in Poso. Conversely, JI and Mujahidin KOMPAK became more relevant, organized and effective in Poso. They even adopted elements from Laskar Jihad's territorial strategy in Ambon. As David McRae notes, the mujahidin sought to "simplify the 'religious geography' by removing settlements that lay between two villages inhabited by coreligionists". ${ }^{131}$ Thus in 2000-01, "each Christian border village was attacked, and two of the Christian strongholdsSepe and Tangkura in Poso Pesisir sub-district—were also over-run". ${ }^{132}$ Above all, however, they were able to think in broader strategic terms, including where the Poso jihad fit into their broader goals of establishing an Islamist counter-society in Indonesia and, ultimately, an Islamic state.

\section{Conclusion}


The Ambon and Poso jihads occupy an important place in the evolution of jihadism in Indonesia as they were the first local jihads after the establishment of JI in 1993 and the end of President Suharto's authoritarian New Order regime in May 1998. They provided JI and KOMPAK with relevance, a leadership role and training camps on Indonesian soil. They also became the testing ground for new or reframed Indonesian jihadi ideas and the skills and training acquired over the previous decade by Indonesians in Pakistan/Afghanistan and the southern Philippines. Being local jihads, Ambon and Poso enabled a far larger number of Indonesians to become involved and exposed to jihadi ideology, especially the idea of establishing an Islamic state in Indonesia. And last but certainly not least, the social bonding experienced during the training, in particular at the Waimurat camp, facilitated the formation of new networks which played a key role in subsequent Indonesian jihadi efforts in Aceh, Mindanao and Syria.

At the same time, the Ambon and Poso jihads differed considerably in the amount of debate they engendered in JI, the approach to training and recruitment, and the degree of organization. The Ambon jihad bordered on anarchy and JI was pushed almost to the point of fracturing, while the Poso jihad was comparatively uncontentious and more organized. As this article has shown, this was largely the result of JI's and Mujahidin KOMPAK's ability to learn from the mistakes of the Ambon jihad. Thus they were able to provide clearer leadership, to embed the training of local volunteers in a broader recruitment process into local affiliate organizations, and to tie Poso ideologically into the wider Indonesian jihadi project. These corrections provided JI and Mujahidin KOMPAK with greater control and greater strategic direction in Poso. They also allowed JI to experiment with establishing an Islamic countersociety as the nucleus of a future Islamic state. The importance of this learning process from Ambon to Poso for the evolution of Indonesian jihadism cannot be overstated. It not only allowed JI to approach the Poso jihad differently, but contributed to JI's further development as an organization, ultimately strengthening its resilience. It prepared the ground for critical reflection in the Indonesian jihadi community after the 2002 Bali bombings ${ }^{133}$ as well as the 2010 Aceh training camp debacle. And the continued ability to reflect and learn is evident in JI's current focus on dakwah and tarbiyya (education) as well as in the shifting dynamics in Indonesia's pro-ISIS generation today.

\section{NOTES}

${ }^{1}$ For a comprehensive discussion of the Poso conflict, see Loraine Aragon, "Communal Violence in Poso, Central Sulawesi: Were People Eat Fish and Fish Eat People", Indonesia 72 
(October 2001): pp. 45-79; Human Rights Watch, Breakdown: Four Years of Communal Violence in Central Sulawesi, 2002, https://www.hrw.org/report/2002/12/04/breakdown/four-years-communal-violence-centralsulawesi; Rinaldy Damanik, Tragedi Kemanusiaan Poso: Menggapai surya pagi melalui kegelapan malam [Poso's Humanitarian Tragedy: Reaching the morning sun through the darkness of the night] (Palu, Indonesia: PBHI \& LPS-HAM, 2003); and Dave McRae, A Few Poorly Organised Men: Inter-Religious Violence in Poso, Indonesia (Leiden, The Netherlands: Brill Academic Publishers, 2013).

${ }^{2}$ For a more detailed discussion of the Ambon conflict see Gerry Van Klinken, "The Maluku Wars: Bringing Society back In", Indonesia No. 71 (April 2001): pp.1-26; Patricia Speyer, "Fire without Smoke and Other Phantoms of Ambon's Violence: Media Effects, Agency, and the Work of Imagination", Indonesia No. 74 (October 2002): pp. 37-58; Jacques Bertrand, "Legacies of the Authoritarian Past: Religious Violence in Indonesia's Moluccan Islands", Pacific Affairs 75, no 1 (April 2002): pp.57-85; Dieter Bartels, "Your God is No Longer Mine: Moslem-Christian Fratricide in the Central Moluccas (Indonesia) After a Half-Millennium of Tolerant Co-Existence and Ethnic Unity" in A State of Emergency: Violence, Society and the State in Eastern Indonesia, edited by Sandra Pannell (Darwin, Australia: Northern Territory University Press, 2003); Jeroen Adam, "How ordinary folk became involved in the Ambon conflict: Understanding private opportunities during communal violence", Bijdragen tot de Taal-, Land en Volkenkunde [Contributions to Language, Land and Ethnography] 166, no 1 (2010): pp, 25-48; Badrus Sholeh, Conflict and Reconciliation in Ambon, Indonesia: Local and National Responses (Saarbrücken, Germany: Lambert Academic Publishing, 2012); Sumanto Al-Qurtuby, Religious Violence and Conciliation in Indonesia: Christians and Muslims in the Moluccas (London, UK: Routledge, 2015).

3 The Poso jihad ceased for just over three years. In 2010-11, it resumed under new leadership and continued until the death of Mujahidin Indonesia Timur (MIT) leader Santoso in July 2016. While jihadi activity has declined since Santoso's death, several MIT members are still believed to be in the mountains near Poso.

${ }^{4}$ KOMPAK (Komite Aksi Penanggulan Akibat Krisis - The Action Committee for Tackling the Consequences of the crisis) was established in 1997 by Dewan Dakwah Islam Indonesia (DDII) in order to alleviate the impact of the 1997-98 Asian financial crisis on Indonesian Muslims. Mujahidin KOMPAK was formed in 2000 during the second year of the Ambon conflict, initially in order to protect KOMPAK's humanitarian aid deliveries but then broadened its remit to protecting and defending Muslims in Ambon and subsequently in Poso. While there was overlap between the membership of KOMPAK and Mujahidin KOMPAK the two were not synonymous. There were KOMPAK members who never became jihadis and there were members of Mujahidin KOMPAK who never became involved in KOMPAK's broader charitable activities outside the Ambon and Poso conflict areas. Mujahidin KOMPAK was disbanded after the 2010 Aceh training camp debacle.

5 Jacques Bertrand, Nationalism and Ethnic Conflict in Indonesia, (Cambridge, UK: Cambridge University Press, 2004); Gerry Van Klinken, Communal Violence and Democratisation: Small Town Wars (London, UK: Routledge 2007); Harold Crouch, Political Reform in Indonesia after Soeharto. Singapore (Singapore: ISEAS, 2010); Yukhi Tajima, The Institutional Origins of Communal Violence: Indonesia's Transition from Authoritarian Rule (Cambridge, UK: Cambridge University Press, 2014). 
6 John Sidel, Riots, Pogroms, Jihad: Religious Violence in Indonesia (Ithaca, New York: Cornell University Press, 2006); Noorhaidi Hasan; Laskar Jihad: Islam, Militancy and the Quest for Identity in Post-New Order Indonesia (Ithaca, New York: Cornell Southeast Asia Program, 2006).

${ }^{7}$ Zachary Abuza, Militant Islam in Southeast Asia: Crucible of terror (Boulder, Colorado: Lynne Rienner Publishers, 2003); Greg Barton, Jemaah Islamiyah and the Soul of Islam (Sydney, Australia: University of New South Wales Press, 2004); Maria A. Ressa, Seeds of Terror (New York City, New York: Free Press, 2004); Ken Conboy, Second Front: Inside Asia's most Dangerous Terrorist Network (Jakarta, Indonesia: Equinox, 2005).

8 Sidney Jones, "The Changing Nature of Jemaah Islamiyah", Australian Journal of International Affairs 59, issue 2 (2005): pp. 169-178; Greg Fealy and Aldo Borgu, Local Jihad: Radical Islam and Terrorism in Indonesia (Barton, Australia: The Australian Strategic Policy Institute, 2005); Solahudin, The Roots of Terrorism in Indonesia: From Darul Islam to Jema'ah Islamiyah (Ithaca, New York: Cornell University Press, 2013); Julie Chernov Hwang, Why Terrorists Quit: The Disengagement of Indonesian Jihadists (Ithaca, New York: Cornell University Press, 2018).

${ }^{9}$ Bertrand, "Legacies of the Authoritarian Past" op. cit.; Bartels, "Your God is No Longer Mine", op. cit.; Adam, "How ordinary folk became involved in the Ambon conflict", op. cit.; Sholeh, op. cit. Conflict and Reconciliation in Ambon; and Qurtuby, Religious Violence and Conciliation in Indonesia, op. cit.

10 Aragon, "Communal Violence in Poso, Central Sulawesi", op. cit.; Damanik, Tragedi Kemanusiaan Poso, op. cit.; McRae, A Few Poorly Organised Men, op. cit.

${ }^{11}$ Kirsten E. Schulze, "Laskar Jihad and the Conflict in Ambon", The Brown Journal of World Affairs 9, No. 1 (Spring 2002): pp.57-69; and Birgit Bräuchler, Cyberidentities at War: Der Molukkenkonflikt im Internet [Cyberidentities at War: The Maluku Conflict on the Internet] (Bielefeld, Germany: Transcript Verlag, 2005).

12 Tito Karnavian, Indonesian Top Secret: Membongkar Konflik Poso (Jakarta, Indonesia: PT Gramedia Pustaka Utama, 2008); Tito Karnavian, Explaining Islamist Insurgencies: The case of Al-Jamaah Al-Islamiyyah and the radicalisation of the Poso conflict, 2000-2007 (London, UK: Imperial College Press, 2014); Julie Chernov Hwang, Rizal Panggabean and Ihsan Ali Fauzi, "The Disengagement of Jihadis in Poso, Indonesia", Asian Survey 53, No 4 (July/August 2013): pp.754-777

${ }^{13}$ International Crisis Group, “Indonesia’s Maluku Crisis”, Asia Briefing No 2 (19 July 2000); International Crisis Group, "Overcoming Murder and Chaos in Maluku”, Asia Report No. 10 (19 December 2000); International Crisis Group, "Indonesia: The Search for Peace in Maluku", Asia Report No. 31 (8 February 2002) International Crisis Group, "Indonesia Backgrounder: How the Jemaah Islamiyah Terrorist Network Operates", Asia Report No. 43 (11 December 2002); International Crisis Group, “Weakening Indonesia's Mujahidin Networks: Lessons from Maluku and Poso", Asia Report No. 103 (13 October 2005); International Crisis Group, "Jihadism in Indonesia: Poso on the Edge", Asia Report No. 127 (24 January 2007); International Crisis Group, "Indonesia: Tackling Radicalism in Poso", Asia Briefing No. 75 (22 January 2008); International Crisis Group, "How Indonesian Extremists Regroup", Asia Report No 228 (16 July 2012); Institute for Policy Analysis of Conflict, "Indonesia's Lamongan Network: How East Java, Poso and Syria are Linked" (April 2015); Institute for Policy Analysis of Conflict, "ISIS in Ambon" (May 2016). 
${ }^{14}$ For a more detailed analysis of JI see International Crisis Group, "How the Jemaah Islamiyah Terrorist Network Operates", op. cit., and Solahudin, The Roots of Terrorism in Indonesia, op. cit.

${ }^{15}$ Author interview with Ali Imron, member of JI, Jakarta, 6 December 2010.

${ }^{16}$ Ibid.

${ }^{17}$ Ali Imron, Sang Pengebom (Jakarta, Indonesia: Penerbit Republika, 2007), p. 57.

${ }^{18}$ Author interview with Ali Imron, Jakarta, 6 December 2010.

${ }^{19}$ Quinton Temby, Jihadists Assemble: The Rise of Militant Islamism in Southeast Asia, unpublished PhD thesis, Australian National University, July 2017, p. 194.

${ }^{20}$ Author interview with Abu Tholut, former head of JI Mantiqi 3, Bekasi, 27 March 2018.

${ }^{21}$ Author interview with Abu Rusydan, former JI Mantiqi 2 member of the JI markaziyah, Kudus, 6 April 2016.

${ }^{22}$ International Crisis Group, "Indonesia Backgrounder: Jihad in Central Sulawesi", Asia Report No. 74 (3 February 2004), p. 4.

${ }^{23}$ Solahudin, The Roots of Terrorism in Indonesia, op. cit., p. 175.

${ }^{24}$ Author interview with Abu Tholut, Bekasi, 27 March 2018.

${ }^{25}$ International Crisis Group, "Jihad in Central Sulawesi”, op. cit., p. 4.

${ }^{26}$ Temby, Jihadists Assemble, op. cit., p. 195.

${ }^{27}$ Author interview with Abu Tholut, Bekasi, 27 March 2018.

${ }^{28}$ Author interview with Abu Rusydan, Kudus, 6 April 2016.

${ }^{29}$ Author interview with Abu Tholut, Bekasi, 27 March 2018.

${ }^{30}$ Author interview with Abu Rusydan, Kudus, 6 April 2016.

${ }^{31}$ Solahudin, The Roots of Terrorism in Indonesia, op. cit., p. 175.

${ }^{32}$ Author interview with Abu Rusydan, Kudus, 6 April 2016.

${ }^{33}$ Author interview with Jibril, former JI volunteer in Ambon, Jakarta, 4 November 2010.

${ }^{34}$ Author interview with Farihin, former JI volunteer in Ambon, Jakarta, 7 April 2017.

${ }^{35}$ Ibid.

${ }^{36}$ Ibid. 
${ }^{37}$ Ibid.

${ }^{38}$ Author interview with Nasir Abas, former head of JI Mantiqi 3, Jakarta, 3 April 2017.

${ }^{39}$ Author interview with Abu Tholut, Bekasi, 27 March 2018.

${ }^{40}$ Ibid.

${ }^{41}$ Author interview with Aris Munandar, head of KOMPAK Solo, Solo, 19 August 2015.

${ }^{42}$ Ibid.

${ }^{43}$ Ibid.

${ }^{44}$ Author interview with Abdullah Sunata, head of KOMPAK Ambon 2000-01, Jakarta, 7 December 2010.

45 Ibid.

46 Ibid.

${ }^{47}$ Ibid.

${ }^{48}$ Author interview with Aris Munandar, Solo, 19 August 2015.

49 Author interview with Abu Rusydan, former Mantiqi 2 member of the JI markaziyah, Mantiqi 2, Kudus, 8 August 2017.

${ }^{50}$ Author interview with Abu Tholut, Bekasi, 27 March 2018.

${ }^{51}$ Author interview with Abu Rusydan, Kudus, 8 August 2017.

${ }^{52}$ Author interview with Ali Imron, Jakarta, 6 December 2010.

${ }^{53}$ Ibid.

${ }^{54}$ International Crisis Group, "Jihad in Central Sulawesi”, op. cit., p. 5.

55 See International Crisis Group, "How Indonesian Extremists Regroup"; Institute for Policy Analysis of Conflict, "Indonesia's Lamongan Network", op. cit.; and Schulze and Liow, "Making Jihadis, Waging Jihad", op. cit.

${ }^{56}$ International Crisis Group, "Jihad in Central Sulawesi”, op. cit., p. 5.

${ }^{57}$ Author interview with Jibril, Jakarta, 4 November 2010.

${ }^{58}$ Ibid.

${ }^{59}$ International Crisis Group, "Jihad in Central Sulawesi", op. cit., p. 4. 
${ }^{60}$ Author interview with Jibril, Jakarta, 4 November 2010.

${ }^{61}$ Author interview with Jek Harun, former KOMPAK volunteer in Ambon, Solo, 18 August 2015.

${ }^{62}$ Ibid.

${ }^{63}$ Author interview with Abu Sayyaf, former KOMPAK volunteer in Ambon, Solo, 17 August 2015.

${ }^{64}$ Author interview with Aput, former Mujahidin KOMPAK member in Ambon, Bekasi, 8 January 2014.

${ }^{65}$ Ibid.

${ }^{66}$ Ibid.

${ }^{67}$ Author interview with Abdullah Sunata, Jakarta, 7 December 2010.

${ }^{68}$ Author interview with Aput, Bekasi, 8 January 2014.

${ }^{69}$ Author interview with Abu Sayyaf, Solo, 17 August 2015.

${ }^{70}$ Schulze, "Laskar Jihad and the Conflict in Ambon”, op. cit.

${ }^{71}$ Author interview with Ramly, former member of Mujahidin KOMPAK in Ambon, Jakarta, 10 April 2017.

${ }^{72}$ International Crisis Group, “Weakening Indonesia’s Mujahedin Networks”, op. cit., p. 7.

${ }^{73}$ International Crisis Group, "Jihad in Central Sulawesi”, op. cit., p. 7.

${ }^{74}$ Author interview with Nasir Abas, Jakarta, 3 April 2017.

${ }^{75}$ Human Rights Watch, Four Years of Communal Violence in Central Sulawesi, op. cit., p. 21.

${ }^{76}$ Author interview with Nasir Abas, Jakarta, 3 April 2017.

${ }^{77}$ Author interview with Abu Rusydan, Kudus, 6 April 2016.

${ }^{78}$ Author interview with Nasir Abas, Jakarta, 3 April 2017.

${ }^{79}$ Author interview with Farihin, Jakarta, 7 April 2017.

${ }^{80}$ International Crisis Group, "Jihad in Central Sulawesi”, op. cit., p. 5.

${ }^{81}$ Imron, Sang Pengebom, op. cit., p. 58.

${ }^{82}$ Author interview with Handzollah, former JI volunteer in Ambon, Solo, 20 August 2015. 
${ }^{83}$ Imron, Sang Pengebom, op. cit., p. 58.

${ }^{84}$ Author interview with Zuheb, former JI volunteer in Ambon, Jakarta, 7 December 2010.

${ }^{85}$ Author interview with Farihin, Jakarta, 7 April 2017.

${ }^{86}$ Author interview with Nasir Abas, Jakarta, 3 April 2017.

${ }^{87}$ Author interview with BR, former Mujahidin Tanah Runtuh member, Palu, 6 August 2017.

${ }^{88}$ Ibid.

${ }^{89}$ Ibid.

${ }^{90}$ Author interview with Iwan Ambo, Mujahidin Tanah Runtuh, Palu, 5 August 2017; author interview with Cecep, Mujahidin Tanah Runtuh, Palu, 5 August 2017; author interview with BR, Palu, 6 August 2017.

${ }^{91}$ Fealy and Borgu, Local Jihad, op. cit., p. 27.

92 Solahudin, The Roots of Terrorism in Indonesia, op. cit., p. 175.

${ }^{93}$ Author interview with Ali Imron, Jakarta, 6 December 2010.

${ }^{94}$ Fealy and Borgu, Local Jihad, op. cit., p. 27.

${ }^{95}$ Solahudin, The Roots of Terrorism in Indonesia, op. cit., p. 193.

${ }^{96}$ International Crisis Group, "Jihad in Central Sulawesi”, op. cit., p. 5.

${ }^{97}$ Author interview with Nasir Abas, Jakarta, 3 April 2017.

${ }^{98}$ Ibid.

${ }^{99}$ Author interview with Abu Tholut, Bekasi, 27 March 2018.

${ }^{100}$ Author interview with Nasir Abas, former head of JI Mantiqi 3, Jakarta, 15 October 2010.

${ }^{101}$ Ibid.

102 Author interview with Abu Rusydan, Kudus, 6 April 2016.

${ }^{103}$ Author interview with Nasir Abas, Jakarta, 15 October 2010.

${ }^{104}$ Author interview with Abu Tholut, Bekasi, 27 March 2018.

${ }^{105}$ Author interview with Farihin, Jakarta, 7 April 2017. 
${ }^{106}$ Author interview with Nasir Rahawarin, Muslim community leader, Badan Imarah Muslim Maluku (BIMM), Ambon, 20 December 2001.

${ }^{107}$ Ibid.

${ }^{108}$ Author interview with Abdullah Sunata, Jakarta, 7 December 2010.

${ }^{109}$ For a comprehensive discussion of the DI rebellions see C. Van Dijk, Rebellion under the Banner of Islam: The Darul Islam in Indonesia (The Hague, The Netherlands: Martinus Nijhoff, 1981).

${ }^{110}$ International Crisis Group, "Indonesia Backgrounder: Why Salafism and Terrorism Mostly Don't Mix”, Asia Report No 83 (13 September 2004), p. 6.

${ }^{111}$ Author interview with Jafar Umar Thalib, Laskar Jihad leader, Kaliurang, 5 April 2002.

112 International Crisis Group, "Why Salafism and Terrorism Mostly Don't Mix”, op. cit., p. 25 .

${ }^{113}$ Author interview with Jafar Umar Thalib, Kaliurang, 5 April 2002.

${ }^{114}$ Author interview with member of Laskar Jihad, Yogyakarta, 27 April 2001.

${ }^{115}$ Schulze, "Laskar Jihad and the Conflict in Ambon”, op. cit.

116 The khawarij, also known as kharijites, appeared during the First Fitna in the seventh century/first Islamic century. The khawarij rejected any man-made law and killed the fourth caliph Ali who was the prophet Mohammed's son-in-law.

${ }^{117}$ Author interview with Aput, Bekasi, 8 January 2014.

${ }^{118}$ Author interview with Ramly, Jakarta, 10 April 2017.

${ }^{119}$ Author interview with Aput, Bekasi, 8 January 2014.

${ }^{120}$ Author interview with Ramly, Jakarta, 10 April 2017.

${ }^{121}$ International Crisis Group, "Jihad in Central Sulawesi”, op. cit., p. 6.

122 Ibid, p. 7.

${ }^{123}$ Author interview with Ramly, Jakarta, 10 April 2017.

${ }^{124}$ Author interview with Abdullah Sunata, Jakarta, 7 December 2010.

125 Ibid.

${ }^{126}$ Author interview with Mahfud, Muslim child fighter, Ambon, 23 February 2011.

${ }^{127}$ Author interview with Abdullah Sunata, Jakarta, 7 December 2010. 
${ }^{128}$ Author interview with Aput, Bekasi, 8 January 2014.

${ }^{129}$ Ibid.

${ }^{130}$ Author interview with Jafar Umar Thalib, Kaliurang, 2 April 2002.

${ }^{131}$ McRae, A few organized men, op. cit., p. 95.

132 Ibid.

${ }^{133}$ See Julie Chernov Hwang, "Dakwah before Jihad: Understanding the Behavior of Jemaah Islamiyah", Contemporary Southeast Asia 41, No. 1 (April 2019): insert page numbers later 